\title{
Pengaruh Kesadaran Linguistik dan Kesadaran Persepsi Visual Terhadap Kemampuan Membaca Permulaan Anak Tunagrahita
}

\author{
Endang Rochyadi \\ Sekolah Pascasarjana Prodi Pengembangan Kurikulum UPI
}

\begin{abstract}
Abstrak: Kajian ini untuk melihat faktor-faktor esensial dari kesadaran linguistik dan kesadaran persepsi visual yang mempengaruhi kemampuan membaca permulaan pada anak tunagrahita. Faktor-kator yang dikaji meliputi kesadaran linguistik (fonem, morfem, semantik dan sintaksis) dan kesadaran persepsi visual (visual discrimination, visual spacial, visual figure and ground, visual memory) yang diduga menjadi prasyarat dalam belajar membaca permulaan. Subjek penelitian berjumlah 32 siswa dari lima SLB di Bandung. Hasil kajian ini menunjukkan, bahwa kedua faktor tersebut memiliki hubungan kuat terhadap kemampuan membaca permulaan anak tunagrahita. Berdasarkan Koefisien Beta secara parsial kesadaran linguistik memiliki hubungan jauh lebih kuat dibandingkan kesadaran persepsi visual. Nilai koefisien path kesadaran linguistik (0.72) sementara pada kesadaran persepsi visual nilai koefisien pathnya (0.25). Akan tetapi ada faktor esensial sebagai prasyarat membaca yang berkaiatan dengan aspek kesadaran linguistik yaitu kesadaran fonem dan sintaksis, sementara faktor esensial pada aspek kesadaran persepsi visual lebih berhubungan dengan discrimination dan visual memory.
\end{abstract}

Kata Kunci: Kesadaran linguistik, kesadaran persepsi visual, membaca permulaan, dan tunagrahita

\begin{abstract}
: this study was conducted to find the essential factors of linguistic awareness and visual perception influencing the beginning reading skill of mentally retarded children. The factors studied include linguistic awareness (morphemes, semantics and syntax) and visual perception awareness (visual discrimination, visual spatial, visual figure-ground, and visual memory) which are assumed to be the prerequisites of learning early reading. The subjects of this research were 32 students from 5 special school in Bandung.

The results show that both of the factors have strong influence towards mentally retarded children early reading skill. However, the Beta Coefficient it was is found that linguistic awareness has stronger relationship compared to the visual perception aspect. The value of the coefficient path in the linguistic awareness is 0.72 , while the coefficient path value for linguistic awareness is 0.25 . This means that linguistic awareness is influencing position as the prerequisite of early reading skill compared to the visual perception aspect. However, if studied further, it is found that not all variables related to either linguistic awareness aspect or visual perception have the same meaningful relationship with children reading skills. The most essential factor of reading prerequisite related to the linguistic awareness is related to the phoneme and syntax awareness, while the essential factor in visual perception is related to the visual discrimination and visual memory.
\end{abstract}

Key words: linguistic awareness, visual perception awareness, beginning reading skill, dan mentally retarded 


\section{Pendahuluan}

Rendahnya kemampuan bernalar anak tunagrahita sebagai faktor yang menimbulkan banyaknya kegagalan dalam belajar membaca. Para ahli pendidikan sepakat bahwa dalam belajar, khususnya yang berkaitan dengan aspek akademik seperti membaca dibutuhkan adanya prasyarat yang berkaitan dengan masalah kematangan.

Sepanjang kematangan ini belum dipenuhi maka akan menimbulkan banyak kegagalan dalam proses belajar berikutnya, dan jika hal ini dipaksakan maka akan muncul akumulasi kegagalan yang menyebar pada semua aspek. Oleh karena itu, sangat layak dipertanyakan dan ditelaah lebih lanjut apakah kegagalan membaca yang terjadi pada anak tunagrahita terkait erat dengan persoalan kesiapan belajar membaca?

Di sekolah, orang yang paling bertanggung jawab untuk melihat persoalan apakah seseorang anak telah cukup matang atau belum untuk belajar membaca adalah guru. Oleh karena itu, apabila hal-hal yang berkaitan dengan pemenuhan kesiapan tersebut tidak terdeteksi secara cepat, akan berakibat buruk terhadap hasil belajar mereka.

Banyak fakta yang menunjuk buruknya hasil belajar membaca pada anak tunagrahita berawal dari prasyarat kesiapan belajar membaca sebagai faktor penyebabnya. Oleh karena itu, pemahaman terhadap prasyarat ini menjadi bagian penting yang harus diketahui seorang guru sebelum ia membawa anak untuk belajar membaca.

Diyakini bahwa pada zaman dahulu persepsi; penglihatan (visual) memiliki pengaruh kuat sebagai prasyarat terhadap keterampilan membaca. Pandangan ini dibangun atas asumsi bahwa persoalan membaca lebih menyangkut pada masalah lambing atau symbol bahasa (alphabet). Oleh karena itu, penekanan utama dalam membentuk kesiapan belajar membaca, lebih difokuskan pada persoalan persepsi visual seperti melakukan diskriminasi terhadap symbol bahasa bahkan jauh ke belakang, anak harus dapat melakukan diskriminasi objek baik yang berkaitan dengan masalah bentuk, ukuran maupun posisi. Asumsi ini sampai sekarang dipegang dandijadikan dasar untuk membangun kesiapan belajar.
Dalam perkembangannya, bahasa ditunjukkan sejalan dengan meningkat usianya, dan penguasaan keterampilan bahasa itu sendiri dibangun melalui proses belajar. Setiap anak biasanya memiliki kaidah sendiri-sendiri dalam belajar, dan sekali kaidah itu dapat ditemukan maka ia akan belajar secara efisien dan efektif. Hal yang sama akan terjadi pula dalam belajar membaca. Kaidah-kaidah dalam belajar secara nyata banyak didasarkan pada kesadaran linguistik atau kesadaran persepsi visual.

Berkenaan dengan pertimbangan tersebut maka masalah penelitian ini dirumuskan sebagai berikut: aspek-aspek kesadaran linguistik dan kesadaran persepsi visual manakah yang paling esensial berpengaruh terhadap kemampuan membaca permulaan anak tunagrahita?

Tujuan dari penelitian ini adalah untuk melihat factor-faktor esensial dari kesadaran linguistik dan kesadaran persepsi visual yang mempengaruhi kemampuan membaca permulaan pada anak tunagrahita.

\section{Kajian literatur}

\section{Kemampuan membaca}

Membaca pada dasarnya merupakan proses sensoris, Slamet dan Vismaia (2003) mengungkapkan "apapun yang dapat dikatakan tentang membaca, tidak dapat dipisahkan dari kenyataan bahwa awalnya membaca merupakan proses sensoris, dimana isyarat dan rangsangan untuk kegiatan membaca itu masuk melalui pintu yang disebut sensor visual dan auditori

Asumsi tersebut didasarkan pada banyaknya fakta dan bukti yang telah dilakukan para peneliti tentang adanya korelasi positif antara kemampuan membaca dengan kematangan membaca. Smith dan Dechant yang dikutip Slamet dan Vismaia (2003:71) mengungkapkan adanya kaitan erat antara kesiapan dan kemampuan membaca. Mereka membuktikan korelasi antara skor tes kesiapan membaca dan MA merentang antara 0,35 dan 0,80. Simpulan mereka berbunyi bahwa pada umumnya tes kemampuan membaca, kesiapan membaca dan MA itu merupakan faktor yang sama.

Apabila simpulan tersebut dikaitkan dengan kondisi anak tunagrahita maka dapat ditarik garis lurus dalam simpulan sementara bahwa faktor 
yang turut menghambat keterampilan membaca pada anak tunagrahita diduga terkait pula dengan masalah yang ada di belakangnya, yaitu persoalan pemenuhan prasyarat kesiapan belajar membaca

Hasil studi yang dilakukan (Park \& Burki; 1943; dalam Santrock; 2007) menyimpulkan bahwa pembaca yang baik memiliki kelemahan penglihatan yang lebih kecil mengenai kelompok kronologis dan kelompok mental.

Berkenaan dengan hal itu Spache \& Tillam dalam Slamet dan Vismaia. (2003) mengungkapkan bahwa kelemahan visual berhubungan langsung dengan ketidak mampuan membaca. Studi lain yang dilakukan Harris (1990) menunjukkan adanya hubungan antara ketidak mampuan membaca dan kelemahan visual. Meskipun demikian, sebahagian orang mulai meragukan; bukankah masalah bahasa itu sesungguhnya lebih menyangkut kepada persoalan bunyi?

Selanjutnya, Haris (1990) mengungkapkan mengungkapkan bahwa faktor terpenting dalam masalah membaca adalah inteligensi umum. Hasil penelitian menunjukkan bahwa terdapat hubungan yang erat antara kemampuan membaca dengan inteligensi seseorang dengan korelasi 84 . (Strang , Traxler: dalam Viismaia, 2003).

Temuan Cohen (1996) melaporkan bahwa pada tingkat pertama tidak ditemukan hubungan signifikan antara skor IQ dan skor kemampuan membaca, tetapi mereka menemukan hubungan di kelas empat di saat mental age (MA)berada di bawah 6 tahun. Lebih lanjut, dilaporkan bahwa porsi kegagalan itu menurun ketika MA naik sampai 6,5 tahun. Menurutnya antara inteligensi dan MA merupakan factor yang sama. Jika hasil penelitian yang disebutkan terakhir itu benar maka ini merupakan isyarat bahwa kegagalan membaca pada anak tunagrahita bukan sematamata karena factor inteligensi, melainkan ada factor lain yang turut mendukung terhadap kegagalan atau keberhasilan membaca seseorang.

Oleh karena itu, sangat dimungkinkan adanya prasyarat lain yang belum terpenuhi berkaitan dengan soal kesiapan belajar membaca. Faktor persepsi misalnya, diduga menjadi bagian yang turut menghambat dalam belajar anak tunagrahita. Masalah persepsi menjadi bagian yang diduga mendukung atas kegagalan belajar membaca mereka.
Dalam pandangan yang berbeda, diyakini bahwa membaca itu lebih merupakan persoalan bahasa dan bahasa itu sendiri merupakan persoalan bunyi di mana prosesnya dilalui lewat sensori auditoris. Jika merujuk pada paham ini maka persoalan yang harus dibangun di dalam kesiapan belajar membaca tidak disandarkan pada proses persepsi visual, melainkan lebih menyangkut kepada proses auditori yaitu kesadaran akan bunyi bahasa atau yang disebut kesadaran linguistik. Bryant, dkk (1998) mengungkapkan bahwa "kesadaran linguistik pada anak sekolah dasar merupakan salah satu perolehan peningkatan keterampilan membaca yang dapat menjadi prasyarat atau fasilitator bagi keterampilan membaca". Hasil penelitian itu menemukan bahwa pelatihan kesadaran fonologis yang diberikan selama pengajaran membaca dapat mengembangkan keterampilan membaca anak, (Bradley \& Brryant; 1991, Cunningham;1990, Hatcher, Hulme \& Ellis; 1994). Temuan Rayner (dalam Santrock, 2007) menyebutkan bahwa membaca membutuhkan penguasaan aturan dasar fonologi, morfologi, sintaksis dan semantik, anak yang buruk tata bahasanya baik dalam kontek bicara maupun mendengar akan mengalami kesulitan dalam membaca.

Secara eksplisit hasil kedua studi tersebut belum memberi gambaran yang tegas, mana di antara kedua pendekatan tersebut yang paling berpengaruh terhadap keterampilan membaca, kesadaran linguistik atau persepsi visual?

Pertanyaan lebih lanjut apakah hasil studi di atas dapat ditarik garis lurus bagi siswa tunagrahita? Pertanyaan-pertanyaan itu muncul, karena gaya belajar pada anak tunagrahita berbeda dengan gaya belajar anak pada umumnya. Kesiapan belajar membaca pada anak tunagrahita dapat dicapai ketika mereka duduk di kelas 3 atau 4.

Penelitian yang dilakukan Herawati Dewi (2007) sedikit memberikan gambaran atas simpulan yang diperolehnya bahwa anak tunagrahita yang memperoleh hasil tinggi pada tes kesadaran linguistik cenderung mendapatkan nilai yang tinggi pula pada tes keterampilan membaca, demikian sebaliknya. Anak yang memperoleh nilai rendah pada kesadaran linguistiknya memperoleh nilai yang rendah pula 
dalam keterampilan membaca-nya. Masalahnya adalah pada aspek kesadaran linguistik yang mana keterkaitan hubungan antara keterampilan membaca dengan kesadaran linguistik itu terjadi. Dalam pertanyaan lain, pada keterampilan membaca yang mana sesungguhnya peran kesadaran linguistik itu menjadi kuat hubungannya dalam membaca; kesadaran akan bunyi fonem, morfem, simantik atau sintaksis? Kehawatiran lebih lanjut, berkaitan dengan penelitian itu tidak mempertimbangkan aspek kesadaran persepsi visual yang nyata-nyata telah dikuasai anak dan berperan kuat atas penguasaan keterampilan membaca yang dicapai mereka.

Merujuk pada hasil penelitian yang dilakukan Goetzinger, Dirks \& Baer (dalam Selamat dan Viasmaia, 2003) tentang signifikansi hubungan kesadaran bunyi dan membaca melalui perbandingannya pada pembaca yang baik dan yang lemah dalam memilih keterampilan auditoris sejalan dengan yang dilakukan Thomson (dalam Rahim, 2007) mengungkapkan bahwa "dari 24 anak pembaca yang baik, ada 16 siswa yang memiliki kemampuan diskriminasi auditoris yang baik pula pada awal masuk sekolah dan dari 24 pembaca yang terburuk, hanya satu orang yang menunjukkan kemampuan diskriminasi yang baik pada awal masuk di tingkat satu.

Perkembangan bahasa anak tunagrahita sering dikatakan tidak seluas dan secepat yang dicapai anak pada umumnya, karena terjadi penundaan atau keterlambatan. (Spreed dalam Farida; 2007) menunjukkan bahwa "anak normal usia 5 dan 6 tahun memiliki kepekaan terhadap sifat-sifat bunyi dan mampu membedakan sifatsifat bunyi (fonem), mereka juga dapat menghasilkan sebahagian bunyi-bunyi dengan benar. Sementara pada anak tunagrahita pada usia mental 7 dan 8 nyaris banyak melakukan kesalahan dalam hal bunyi, di antara mereka juga banyak yang mengalami kekacauan artikulasi, kualitas suara dan irama". Oleh karena itu, anak tunagrahita memperlihatkan perkembangan pengucapan yang tertunda, mereka lebih tua dari anak pada umumnya ketika membuat bunyi-bunyi.

Dalam hal morfologis anak-anak yang tidak mengalami ketunagrahitaan menguasai sejumlah morfem terikat, demikian pula halnya pada anak tunagrahita. Namun, mereka menunjukkan tahapan yang lebih rendah (Bredberry; 1967 dan Erwin dalam Selamat dan Vismaia: 2003). Sedangkan perkembangan dalam sintaksis sebagaimana yang dikemukakan Williams dan Tellman (dalam Glass and Cohen, 1996) dalam penelitiannya terhadap anak tunagrahita (ringan), menyebutkan bahwa "anak-anak normal dan anak superior pada berbagai tingkat usia kronologis (CA), yaitu mulai dari usia 4-11 tahun dan ketika mereka diberikan dua tugas menggabungkan kata dan penggunaan kata (kata kerja dan kata keterangan), menjelaskan bahwa masing-masing kelompok pada dasarnya menunjukkan pola perkembangan yang sama dan memperlihatkan kemampuan dalam merangkai kalimat secara teratur, sekalipun pada anak tunagrahita tugastugas itu diselesaikan lebih lambat".

Berkenaan dengan kesadaran linguistik, Lyster (2002) membaginya dalam 6 aspek, yaitu 1) identifikasi panjang kata; 2) identifikasi suku kata; 3) pembentukkan kata; 4) peleburan bunyi; 5) pemisahan fonem; dan 6 ) penghapusan bunyi. Keenam faktor inilah yang turut mendukung kemampuan membaca anak. Apabila merujuk pada aspek kesadaran linguistik yang dikemukakan Lyster, dan diduga kuat menjadi prasyarat dalam membaca, pertanyaannya adalah; aspek kesadaran linguistik mana yang paling esensial berpengaruh terhadap kesiapan membaca anak tunagrahita?

Dalam pandangan yang berbeda dan menitikberatkan pada masalah sensori visual sebagai faktor prasyarat dalam membaca menunjukkan adanya korelasi postif terhadap kemampuan membaca seseorang. Keyakinan yang menekankan pada kesadaran persepsi visual, dibangun atas asumsi bahwa persoalan membaca lebih menyangkut pada masalah lambang bahasa (alphabet), Oleh karena itu, penekanan utama dari kesiapan belajar membaca, lebih diakibatkan karena masalah persepsi visual, seperti; diskriminasi terhadap simbol bahasa, visual memory, spasial, maupun figure and ground merupakan indikator penting dalam membaca. Keyakinan ini sampai sekarang masih dipegang dan dijadikan dasar dalam membangun kesiapan belajar membaca. Berkenaan dengan masalah persepsi visual Lenner dalam Molyono (1999) melihat ada lima jenis persepsi visual yang berperan kuat 
dalam membaca yaitu: 1) hubungan keruangan (spasial relation); 2) diskriminasi visual (visual diskrimanation); 3) objek dan latar (figure and ground); 4) visual closure; dan 5) mengingat (visual memory).

Dari dua cara pandang yang terkesan kontradiktif di dalam melihat prasyarat serta dampak yang ditimbulkan terhadap kemampuan membaca, menjadi menarik untuk dikaji lebih jauh dalam bentuk penelitian deskriptif analitik. Antara symbol dan bunyi dalam aktivitas membaca merupakan dua hal yang tidak dapat dipisahkan dan harus dipersepsi secara bersamaan. Dalam aktivitas membaca, simbol (huruf) itu harus dibunyikan dan setiap apa yang akan dibunyikan harus sesuai dengan symbol yang ditampilkan.

Dalam pengertian lain; kesadaran linguistik dan kesadaran persepsi visual dalam kaitannya dengan membaca, ibarat dua sisi mata uang di mana sisi yang satu tidak dapat dipisahkan dari sisi lainnya. Oleh karena itu, keterampilan membaca harus dibangun oleh kedua aspek tersebut.

Apabila kedua prasyarat dasar dalam membaca itu dikaitkan dengan proses mental dalam penerimaan informasi, ternyata stimulan yang dilihat (persepsi visual) dan didengar (persepsi auditoris), diolah melalui proses mental yang sama. Baik informasi itu masuk di otak, akan diolah pada tempat yang berbeda. Stimulan yang masuk melalui sensori visual seperti symbol bahasa, akan ditransfer pada hemisfer kanan, sedangkan stimulan yang masuk melalui sensori auditoris seperti bunyi bahasa akan ditransfer pada hemisfer kiri. Selanjutnya, kedua informasi ini akan direkam dan disimpan dalam memori.

Dalam teori belajar, salah satu cara agar informasi itu tersimpan dalam memory diperlukan adanya latihan dan pengulangan. Bagi anak tunagrahita proses belajar melalui latihan dan pengulangan merupakan prinsip yang sangat mendasar.

Begitu pula halnya jika di kaitkan dengan teori multiple intelligent, di mana aspek "spasial" merupakan salah satu komponen dari kecerdasan seseorang di dalam proses kognitif, maka masalah kesadaran persepsi visual menjadi penting untuk dijadikan dasar pertimbangan dalam masalah membaca. Sama halnya dengan masalah kesadaran linguistik sebagai sensibilitas terhadap bunyi, ritme, arti kata-kata, dan fungsi bahasa (Gardner, 1998). Colin \& Nicholl (2002) sebagaimana yang mereka jelaskan bahwa setiap orang memiliki jenis kecerdasaan yang bervariasi, kecerdasankecerdasan itu berkombinasi sebanyak wajah dan pribadi individu manusia. Hasil penelitiannya di Harvard menunjukkan bahwa anak-anak berusia 5 tahun menempatkan profil kekuatan dan kelemahan khas masing-masing, dan ketika dewasa, sebahagian orang memiliki satu atau dua kecerdasan yang benar-benar dikembangkan dengan baik. Oleh karena itu, menjadi sangat dimungkinkan aspek visual dan dan auditory itulah yang memberi dukungan kuat atas keberhasilan anak tunagrahita dalam hal membaca, sebab kedua aspek itu nyata-nyata memiliki pengaruh positif terhadap keterampilan membaca seseorang.

Dalam perkembangannya, bahasa ditunjukkan sejalan dengan meningkat usianya, dan penguasaan keterampilan berbahasa itu sendiri dibangun melalui proses belajar. Setiap anak biasanya memiliki kaidah sendiri-sendiri dalam belajar, dan sekali kaidah belajar itu dapat ditemukan, maka ia akan belajar secara efisien dan efektif. Hal yang sama akan terjadi pula dalam belajar membaca. Kaidah-kaidah dalam belajar membaca secara nyata banyak didasarkan kepada kesadaran linguistik atau kesadaran persepsi visual.

\section{Metodologi Penelitian}

Kajian ini bersifat deskriptif analitik untuk mencari factor-faktor esensial dari kesadaran linguistik dan kesadaran persepsi visual yang paling berpengaruh terhadap kemampuan membaca permulaan pada anak tunagrahita (ringan). Dalam penelitian ini ada dua variabel bebas, yaitu pertama; kesadaran linguistik dengan subvariabel: 1) kesadaran bunyi huruf (fonem); 2) kesadaran bunyi kata (morfem); 3) kesadaran makna kata (simantik); dan 4) kesadaran pemahaman kalimat atau isi cerita (sintaksis). Kedua adalah kesadaran persepsi visual dengan sub variabel: 1) hubungan keruangan (spasial relation); 2) diskriminasi visual (visual discrimanation); 3) objek dan latar (figure and ground); 4) mengingat secara visual (visual memory). Sebagai variabel terikatnya adalah keterampilan kemampuan membaca permulaan 
yang mencakup: 1) penguasaan huruf (latter identification); 2) suku kata (sound blending); 3) kata (word-attack) dan memahami isi ceritra sederhana/kalimat (syntaxis). Kedua variable yang dimaksud dapat divisualisasikan.

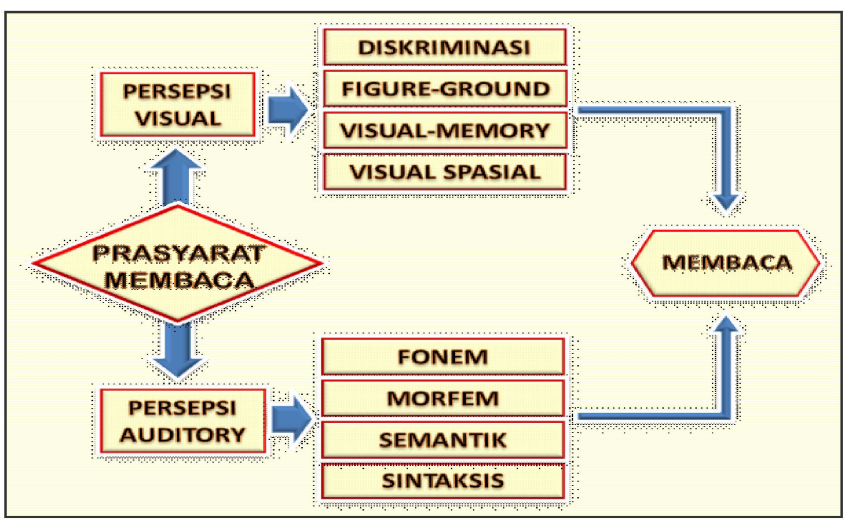

\section{Gambar 2. Hubungan Kesadaran Persepsi Visual dan Kesadaran Linguist dalam Memabaca}

Subjek penelitian ini berjumlah 32 siswa yang tersebar di lima SLB kota dan kabupaten Bandung. Oleh karena itu penetapan sample ini bersifat purposif atau dikenal dengan istilah purposif sampling. Cara ini dilakukan dengan pertimbangan bahwa jumlah subjek penelitian (anak) relatif sedikit dan tersebar di beberapa sekolah baik di kota maupun kabupaten Bandung, dengan variabel kontrol; MA (7-11), IQ (50-75), tidak memiliki kelainan pendengaran dan visual, mereka telah/sedang belajar membaca tetapi dinyatakan gagal.

Prosedur penelitian ini ditempuh langkahlangkah sebagai berikut: 1) Menyusun instrumen kesadaran linguistik kesadaran persepsi visual, dan membaca permulaan; 2) Uji coba instrumen yang bertujuan untuk melihat tingkat validitas isi dan kontruksi (validitas kontruksi digunakan pendapat ahli (judment expert) sebanyak 3 orang, sedangkan validitas isi digunakan pada siswa sebanyak 5 orang siswa tunagrahita). Sedangkan untuk melihat realibilitas digunakan analisis statistik dengan rumus K-R.21;3) Melakukan asesmen yang berkaitan dengan kesadaran linguistik, kesadaran persepsi visual dan kemampuan membaca sehingga ditemukan profil kemampuan pada setiap aspek dari ketiga variabel (kesadaran linguistik, persepsi visual dan membaca); 4) Menganalisis hasil asesmen analisis hasil asesmen dilakukan dengan menggunakan analisis jalur (path analysis). Melalui proses; 1 ) uji normalitas variabel dengan menggunakan One Sample Kolmogorov-Smirnov Test; 2) Uji kandidat, yang berfungsi untuk memilih variabel menjadi variabel yang dapat dianalisis melalui multivariate (Path analysis) berdasarkan analisis variat (uji korelasi) dengan nilai kebermaknaan $<=0.25$; 3) rumus yang digunakan adalah Pearson Correlation Test; 4) selanjutnya dianalisis dengan menggunakan perhitungan analisis jalur (path analysis).

\section{Hasil Penelitian dan Bahasan}

\section{Hasil penelitian}

Secara prinsip penelitian ini untuk menggali factorfaktor yang paling berpengaruh dari kesadaran linguistik dan kesadaran persepsi visual terhadap kemampuan membaca permulaan pada anak tunagrahita, untuk kemudian dianalisis melalui analisis statistk, sehingga ditemukan aspek-aspek mana dari kedua variabel (kesadaran linguistik dan kesadaran persepsi visual) yang paling esensial berpengaruh terhadap membaca permulaan.

Pengambilan data tentang kesadaran linguistik dan kesadaran persepsi visual dan membaca permulaan kepada tiga puluh dua subjek penelitian yang tersebar di lima SLB Bagian C (tunagrahita) wilayah kota dan kabupaten Bandung dilaksanakan mulai tanggal 8 September s/d 6 November 2008. Beberapa persiapan sebelum kegiatan penelitian adalah sebagai berikut 1) mempersiapkan instrumen; 2) menghubungi tim ahli untuk kepentingan validasi instrumen; 3) membuat panduan asesmen untuk pengumpulan data; dan 4) mengkoordinir para guru SLB untuk diberikan pelatihan tentang pengambilan data melalui kegiatan asesmen kesadaran linguistik, kesadaran persepsi visual dan membaca yang dilaksanakan yaitu; pada tanggal 2 September 2008 dan bertempat di SLB Sumbersari yang diikuti oleh 6 orang guru.

Selanjutnya tanggal 4 September 2008 bertempat di kampus UPI dan diikuti oleh 8 orang guru. Adapun sumber data dan waktu pengumpulan pelaksanaan yang tersebar di 5 sekolah seperti tampak pada Tabel 1. 
Perolehan data ini diungkap melalui proses asesmen dengan menggunakan instrumen yang telah diuji validitas dan realibilitasnya. Secara umum anak yang dijadikan subjek penelitian ini memiliki mental age (MA) merentang dari $7 \mathrm{~s} / \mathrm{d} 11$, dengan tingkat kecerdasan (IQ) antara 60-70, mereka juga tidak memiliki gangguan pendengaran dan penglihatan yang duduk kelas 3, 4, 5, dan 6. Semua subjek penelitian ini pada secara statistik ketiga variable menunjuk pada angka distribusi normal. Ini berarti analisis statistik dengan menggunakan analisis jalur (path analysis) dapat dilakukan sebagai persyaratan untuk perhitungan analisis jalur.

Untuk sampai pada perhitungan analisis jalur; langkah selanjutnya adalah melakukan uji kandidat tentang pengaruh aspek-aspek kesadaran linguistik dan persepsi visual yang

Tabel 1. Sumber Data dan Pelaksanaan Penelitian

\begin{tabular}{|c|c|c|c|c|c|c|c|c|c|c|c|c|}
\hline \multirow[t]{3}{*}{ NO } & \multirow[t]{3}{*}{ LOKASI SEKOLAH } & \multicolumn{9}{|c|}{ IDENTITAS SISWA } & \multirow[t]{3}{*}{ pLH } & \multirow{3}{*}{$\begin{array}{c}\text { TANGGAL } \\
\text { PELAKSANAAN }\end{array}$} \\
\hline & & \multicolumn{4}{|c|}{$\overline{K L S}$} & \multicolumn{5}{|c|}{ MA } & & \\
\hline & & 3 & 4 & 5 & 6 & 7 & 8 & 9 & 10 & & & \\
\hline 1 & SLB-C Sumbersari- & - & 2 & 2 & 2 & - & - & 2 & 2 & - & 6 & $8 \mathrm{~s} / \mathrm{d} 19$ Sept 2008 \\
\hline 2 & SLB-C/B Buah Batu & 1 & 2 & 1 & 1 & - & 1 & 1 & 3 & - & 5 & $\begin{array}{l}22 \mathrm{~s} / \mathrm{d} 30 \text { Sept } \\
2008\end{array}$ \\
\hline 3 & SLB-C/B YPLB Kopo & 2 & 1 & 1 & 1 & 2 & 2 & 1 & - & $\overline{1}$ & 5 & $6 \mathrm{~s} / \mathrm{d} 16$ Okt 2008 \\
\hline 4 & SLB-YPLB C/B- Cicalengka & 2 & 2 & 2 & 3 & 1 & - & 1 & & 2 & 9 & 20 s/d 29 Okt 2008 \\
\hline 5 & SLB-A/B/C Kab.Kota Cimahi & 1 & 2 & 2 & 2 & 1 & 2 & 1 & 2 & 1 & 7 & 27 Okt s/d 6 Nop \\
\hline & JUMLAH & 6 & 9 & 8 & 9 & 3 & 3 & 4 & & 2 & 32 & \\
\hline
\end{tabular}

dasarnya telah atau sedang mengikuti proses belajar membaca, namun berdasarkan penilaian para guru, mereka dinyatakan gagal atau belum dapat membaca.

Untuk melihat aspek mana yang paling esensial dari kedua prasyarat membaca yaitu; kesadaran linguistik dan kesadaran persepsi visual terhadap kemampuan membaca permulaan perlu dilakukan perhitungan statistik. Untuk kepentingan ini, peneliti menggunakan analisis jalur (path analysis). Berkenaan dengan perhitungan statistik tersebut, ada beberapa langkah yang dilakukan.

\section{Uji normalitas}

Untuk menguji normalitas variabel tentang pengaruh aspek kesadaran linguistik dan kesadaran persepsi visual terhadap membaca, digunakan One Sample Kolmogorov-Smirnov Test. Berdasarkan perhitungan tersebut maka hasil uji normalitas ini dinyatakan berdistribusi normal dengan kisaran angka 0,303 untuk linguistik dan 0.623 untuk visual dan 0,976 untuk membaca permulaan dan jika ketentuan $(p>0,05)$ maka diduga paling esensial terhadap membaca. Uji kandidat, berfungsi untuk memilih variabel menjadi variabel yang dapat dianalisis melalui multivariate (path analysis) berdasarkan analisis variat (uji korelasi) dengan nilai kebermaknaan $<=0.25$

Hasil analisis uji kandidat dengan Pearson Correlation Test tentang pengaruh aspek-aspek kesadaran linguistik dan kesadaran persepsi visual diduga paling esensial terhadap membaca dapat dilihat pada Tabel 2 . 
Tabel 2. Uji Kandidat tentang pengaruh aspekaspek kesadaran linguistik dan persepsi visual yang paling esensial terhadap membaca

\begin{tabular}{|c|c|c|}
\hline \multirow[t]{2}{*}{ Variabel } & \multicolumn{2}{|c|}{ Uji Kandidat Pemodelan* } \\
\hline & Nilai $r$ & Nilai p \\
\hline Linguistik & 0,95 & $<0,001$ \\
\hline Fonem & 0,98 & 0,002 \\
\hline Morfem & 0,95 & $<0,001$ \\
\hline Semantik & 0,62 & 0,020 \\
\hline Sintaksis & 0,96 & $<0,001$ \\
\hline Visual & 0,96 & $<0,001$ \\
\hline $\begin{array}{l}\text { Diskriminasi } \\
\text { bentuk }\end{array}$ & 0,86 & 0,023 \\
\hline Spasial & 0,86 & 0,016 \\
\hline Figur Ground & 0,75 & 0,001 \\
\hline Memory & 0,96 & $<0,001$ \\
\hline
\end{tabular}

${ }^{*}$ Pearson Correlation Test $(p \leq 0,25)$

Angka-angka yang diperoleh berdasarkan perhitungan uji kandidat dengan Pearson Correlation Test pada Tabel 2, menunjuk pada variabel yang diteliti lebih lanjut didasarkan pada pengaruh variabel independen, yaitu aspek kesadaran linguistik dan kesadaran persepsi visual terhadap variabel dependen membaca ketika variabel-variabelnya harus memenuhi kriteria yaitu nilai pd" 0,25.

Berdasarkan pada kriteria tersebut maka semua variabel baik yang berkaitan dengan aspek kesadaran linguistik yaitu; kesadaran tentang bunyi fonem, morfem, simantik dan sintaksis, maupun variabel yang berkaitan dengan aspek kesadaran persepsi visual, yaitu diskriminasi visual, visual spasial, latar dan objek (figure and ground) dan visual memori dapat dianalisis lebih lanjut dengan menggunakan uji kolinearitas untuk kepentingan lebih lanjut dalam perhitungan analisis jalur (path analysis).

\section{Uji Kolinearitas}

Uji kolinearitas (Pearson Correlation Test) dimaksudkan untuk melihat korelasi kuat antara variabel independen di antara aspek-aspek kesadaran linguistik dan kesadaran persepsi visual yang berpengaruh terhadap membaca (dependent). Berdasarkan hasil analisis uji kolinearitas variabel independen pada aspekaspek kesadaran linguistik dan persepsi visual terhadap membaca dapat dijelaskan pada Tabel 3.

Melihat angka-angka yang diperoleh berdasarkan perhitungan uji kolineritas melalui Pearson Correlation Test pada tabel 3 dengan kriteria nilai $r<0,80$ maka data tersebut dapat dianalisis lebih lanjut dengan menggunakan perhitungan analisis jalur (path analysis) untuk melihat variabel-variabel mana dari kedua aspek (kesadaran linguistik dan kesadaran persepsi visual) yang paling esensial berpengaruh terhadap membaca.

\section{Pengaruh aspek kesadaran linguistik dan persepsi visual yang paling esensial terhadap membaca}

Berdasarkan hasil perhitungan, secara garis besar kedua variabel dari kesadaran linguistik dan kesadaran persepsi visual menunjuk pada angka

Tabel 3. Uji Kolinearitas Tentang Pengaruh Aspek-aspek Kesadaran Linguistik dan Kesadaran Persepsi Visual Terhadap Membaca

\begin{tabular}{|l|c|c|c|c|c|c|c|c|}
\hline \multirow{2}{*}{ Variabel } & \multicolumn{8}{|c|}{ Uji Kolinearitas $(\mathbf{r})^{*}$} \\
\cline { 2 - 9 } & $\left(X_{1}\right)$ & $\left(X_{2}\right)$ & $\left(X_{3}\right)$ & $\left(X_{4}\right)$ & $\left(X_{5}\right)$ & $\left(X_{6}\right)$ & $\left(X_{7}\right)$ & $\left(X_{8}\right)$ \\
\hline Fonem $\left(X_{1}\right)$ & $\mathbf{1}$ & $\mathbf{0 , 7 9}$ & $-\mathbf{0 , 0 9}$ & $\mathbf{0 , 7 0}$ & $\mathbf{0 , 3 5}$ & $\mathbf{0 , 3 8}$ & $\mathbf{0 , 1 9}$ & $\mathbf{0 , 4 4}$ \\
\hline Morfem $\left(X_{2}\right)$ & 0,79 & $\mathbf{1}$ & $\mathbf{0 , 0 2}$ & $\mathbf{0 , 6 8}$ & $\mathbf{0 , 2 5}$ & $\mathbf{0 , 3 4}$ & $\mathbf{0 , 4 3}$ & $\mathbf{0 , 6 4}$ \\
\hline Semantik $\left(X_{3}\right)$ & $-0,09$ & 0,02 & $\mathbf{1}$ & $-\mathbf{0 , 0 4}$ & $\mathbf{0 , 0 3}$ & $\mathbf{0 , 0 9}$ & $\mathbf{0 , 1 8}$ & $\mathbf{- 0 , 0 5}$ \\
\hline Sintaksis $\left(X_{4}\right)$ & 0,70 & 0,68 & $-0,04$ & $\mathbf{1}$ & $\mathbf{0 , 5 0}$ & $\mathbf{0 , 4 9}$ & $\mathbf{0 , 4 6}$ & $\mathbf{0 , 5 7}$ \\
\hline Diskriminasi $\left(X_{5}\right)$ & 0,35 & 0,25 & 0,03 & 0,50 & $\mathbf{1}$ & $\mathbf{0 , 6 7}$ & $\mathbf{0 , 4 1}$ & $\mathbf{0 , 3 6}$ \\
\hline Spasial $\left(X_{6}\right)$ & 0,38 & 0,34 & 0,09 & 0,49 & 0,67 & $\mathbf{1}$ & $\mathbf{0 , 2 2}$ & $\mathbf{0 , 4 9}$ \\
\hline Figur Ground $\left(X_{7}\right)$ & 0,19 & 0,43 & 0,18 & 0,46 & 0,41 & 0,22 & $\mathbf{1}$ & $\mathbf{0 , 6 2}$ \\
& & & & & & & & \\
\hline Memory $\left(X_{8}\right)$ & 0,44 & 0,64 & $-0,05$ & 0,57 & 0,36 & 0,49 & 0,62 & $\mathbf{1}$ \\
\hline
\end{tabular}

*Pearson Correlation Test $(r<0,8)$ 
koefisien korelasi yang sangat tinggi, sekalipun memiliki keterhubungan (koefisien path) yang berbeda. Pada aspek kesadaran linguistik diperoleh nilai korelasi sebesar $(r=0,95)$ dan koefisien path $(0,72)$. Kesadaran persepsi visual diperoleh nilai korelasi sebesar $(r=0,96)$, dengan koefisien path $(0,25)$. Hal ini dapat diartikan bahwa hubungan antara kedua variabel, yaitu kesadaran linguistik dan kesadaran persepsi visual memiliki peran yang sangat esensial terhadap membaca, sekalipun memiliki koefisien beta yang berbeda. Untuk lebih jelasnya perolehan angka-angka tersebut dapat dilahat pada pada Tabel 4.

Tabel 4. Hubungan aspek-aspek kesadaran linguistik dan persepsi visual terhadap membaca

\begin{tabular}{|l|c|c|c|c|c|}
\hline \multirow{2}{*}{ Variabel } & \multicolumn{5}{|c|}{ Kemampuan Membaca } \\
\cline { 2 - 6 } & $r$ & $\begin{array}{c}\text { Koefisien } \\
\text { Path }\end{array}$ & Nilai $\left.\mathrm{p}^{*}\right)$ & $\mathrm{R}^{2}$ & $1-\mathrm{R}^{2}$ \\
\hline & 0,97 & & & 0,93 & 0,07 \\
\hline Linguistik & 0,95 & 0,72 & 0,001 & & \\
\hline Visual & 0,96 & 0,25 & 0,200 & & \\
\hline
\end{tabular}

*Path Analysis (pd"0,05)

Dari Tabel 4, kedua variabel baik pada kesadaran linguistik maupun kesadaran persepsi visual terhadap membaca secara keseluruhan diperoleh angka sebesar $(93,0)$ dengan koefisien korelasi sebesar $(0,97)$. Jika besar nilai total pengaruh yang dihasilkan berdasarkan nilai residu dari kemampuan membaca adalah $(7,0 \%)$ maka nilai variabel residu tersebut menunjukkan adanya faktor lain yang turut mempengaruhi dan tidak terdentifikasi dalam variabel penelitian atas peningkatan atau penurunan kemampuan membaca pada koefisien korelasi determinasi sebesar 0,93. Dengan demikian, dapat disimpulkan bahwa kedua variable, yaitu aspek kesadaran linguistik dan persepsi visual berpengaruh kuat terhadap membaca. Namun, jika dilihat berdasarkan Koefisien Beta secara parsial, tampak bahwa aspek kesadaran linguistik memiliki pengaruh lebih kuat dan angka itu menunjuk pada nilai koefisien path sebesar $(0,72)$ dibandingkan kesadaran presepsi visual dengan nilai koefisien path sebesar $(0,25)$. Secara visual pengaruh tersebut dapat disajikan pada Gambar 1.

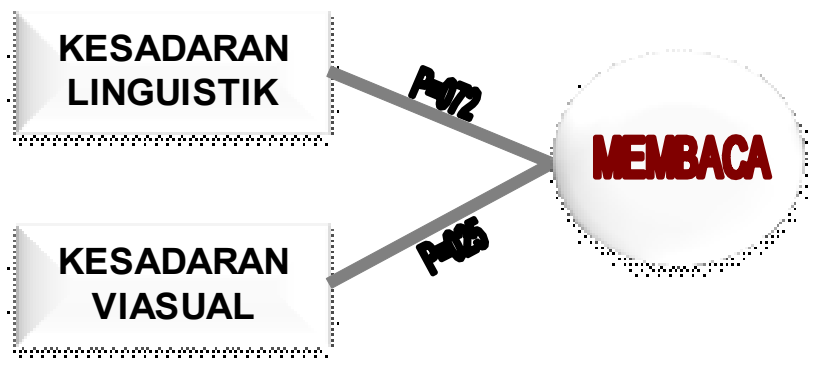

Gambar 1. Pengaruh aspek kesadaran linguistik dan persepsi visual terhadap membaca.

Untuk melihat lebih rinci, variabel mana dari kesadaran linguistik seperti kesadaran bunyi fonem, morfem, simantik dan sintaksis, serta variabel mana dari kesadaran persepsi visual seperti: diskriminasi bentuk, pemahaman akan ruang (spasial), kemampuan melihat latar dan objek dari latar (figure and ground), serta kemampuan mengingat secara visual (visual memory) terhadap membaca dapat dijelaskan pada Tabel 5.

Tabel 5. Hubungan aspek-aspek kesadaran linguistik dan kesadaran persepsi visual yang paling esensial terhadap membaca

\begin{tabular}{|l|c|c|c|c|c|}
\hline \multirow{2}{*}{ Variabel } & \multicolumn{5}{|c|}{ Kemampuan Membaca } \\
\cline { 2 - 6 } & $r$ & $\begin{array}{c}\text { Koefisien } \\
\text { Path }\end{array}$ & Nilai $\mathrm{p}^{*}$ ) & $\mathrm{R}^{2}$ & $1-\mathrm{R}^{2}$ \\
\hline & 0,99 & & & 0,99 & 0,01 \\
\hline Fonem & 0,98 & 0,23 & 0,323 & & \\
\hline Morfem & 0,95 & 0,00 & 0,997 & & \\
\hline Simantik & 0,62 & $-0,25$ & 0,019 & & \\
\hline Sintaksis & 0,96 & 0,33 & 0,000 & & \\
\hline $\begin{array}{l}\text { Diskriminasi } \\
\text { bentuk }\end{array}$ & 0,86 & 0,34 & 0,577 & & \\
\hline Spasial & 0,86 & $-0,24$ & 0,050 & & \\
\hline Figur Ground & 0,75 & 0,16 & 0,095 & & \\
\hline Memori & 0,96 & 0,42 & 0,052 & & \\
\hline
\end{tabular}

*Path Analysis (pd"0,05)

Berdasarkan Tabel 5, maka secara keseluruhan terlihat bahwa hubungan dari masing-masing variabel kesadaran linguistik (Fonem, Morfem, Simantik, Sintaksis) dan persepsi visual (Diskriminasi bentuk, Spasial, figure ground, Memory) terhadap membaca diperoleh angka sebesar $(99,0 \%)$ dengan koefisien korelasi yang sama sebesar 0,99. Ini menunjukkan bahwa aspekaspek kesadaran linguistik dari (Fonem, Morfem, Simantik, Sintaksis) dan persepsi visual dari (Diskriminasi bentuk, Spasial, figure ground, Memory) menunjukkan adanya hubungan yang 
kuat terhadap membaca, hal ini ditunjukkan dengan besarnya nilai total hubungan yang dihasilkan berdasarkan nilai residu dari kemampuan membaca sebesar $1,0 \%$. Nilai variabel residu tersebut menunjukkan adanya faktor lain di luar variabel penelitian yang tidak teridentifikasi dalam penelitian namun turut mempengaruhi adanya peningkatan atau penurunan terhadap kemampuan membaca dengan koefisien korelasi sebesar 0,99. Semua ini tampak terlihat pada aspek-aspek kesadaran linguistik (Fonem, Morfem, Simantik, Sintaksis) dan persepsi visual (diskriminasi bentuk, spasial, figure-ground, memory) yang menunjukkan adanya hubungan sangat kuat terhadap membaca.

Apabila hasil perhitungan itu merujuk pada Interpretasi Koefisien Determinasi dari Sitepu (1995:18) seperti disajikan pada tebel 6 .

Tabel 6. Interpretasi Koefisien Determinasi

\begin{tabular}{|c|l|}
\hline $\begin{array}{c}\text { Interval } \\
\text { Koefisien }\end{array}$ & \multicolumn{1}{c|}{ Tingkat Pengaruh } \\
\hline $0-4$ & Rendah atau lemah sekali \\
\hline $5-16$ & Rendah tapi pasti \\
\hline $17-48$ & Cukup kuat \\
\hline $49-81$ & Tinggi atau kuat \\
\hline $82-100$ & Sangat tinggi atau kuat sekali \\
\hline
\end{tabular}

Sumber : Nirwana Sk. Sitepu, 1995: 18

Berdasarkan interpretasi koefisien diterminasi seperti terlihat pada Tabel 6 maka dalam aspek kesadaran linguistik, terlihat bahwa variabel yang berkaitan dengan fonem (0.23) dan sintaksis (0.33) menjadi faktor yang cukup esensial berpengaruh terhadap membaca. Sementara pada aspek kesadaran persepsi visual yaitu variabel yang berkaitan dengan diskriminasi $(0.34)$ dan visual memori (0.42) merupakan faktor yang cukup esensial berpengaruh terhadap kemampuan membaca. Jika divisualisasikan maka dapat dilihat pada Gambar 2.

Berdasarkan hasil pengolahan data tersebut, hasil analisis menunjukkan adanya pengaruh variabel independen yang sangat kuat terhadap variabel dependen sebesar 0,99 $=99,0 \%$ dan bisa dikatakan bahwa terdapat hubungan yang tinggi atau sangat kuat. Dengan demikian, dapat disimpulkan bahwa secara keseluruhan aspekaspek kesadaran linguistik dan persepsi visual

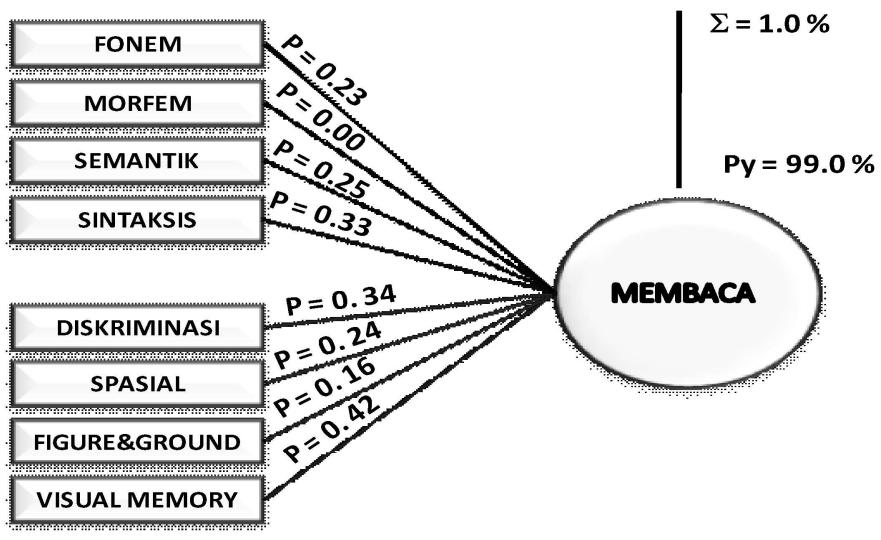

Gambar 2. Diagram Jalur Hubungan aspekaspek kesadaran linguistik dan persepsi visual yang paling esensial terhadap membaca

memiliki pengaruh sangat kuat terhadap kemampuan membaca dengan besar pengaruh $99,0 \%$. Adapun indikator variabel yang paling esensial pada aspek kesadaran linguistik terjadi pada kesadaran bunyi fonem dan sintaksisi sedangkan pada aspek kesadaran persepsi visual indikator variabel yang paling esensial terjadi pada diskriminasi dan memori.

Secara rinci hubungan aspek kesadaran linguistik dan aspek kesadaran persepsi visual dengan aspek-aspek dari kemampuan membaca (huruf, suku kata, kata dan kalimat/Paragraf) dapat dijelaskan pada Tabel 7.

Berdasarkan Tabel 7, terlihat bahwa hubungan aspek-aspek kesadaran linguistik (fonem, morfem, simantik, dan sintaksisi) dan persepsi visual (Diskriminasi Bentuk, Spasial, Figur Ground, Memori) yang paling esensial terhadap membaca huruf yang sangat kuat yaitu memori dari presepsi visual dengan koefisien korelasi sebesar 0,98 sedangkan yang paling kecil adalah simantik dari kesadaran linguistik dengan koefisien korelasi sebesar 0,79 sekalipun masih termasuk pada kategori kuat.

Adapun hubungan aspek-aspek kesadaran linguistik dan persepsi visual yang paling esensial terhadap membaca suku kata, yang paling kuat terletak pada aspek sintaksis dari kesadaran linguistik dengan koefisien korelasi sebesar 0,98, sedangkan hubungan yang paling kecil terjadi pada simantik dengan koefisien korelasi 0,55 sekalipun angka itu masih ada pada kategori kuat. Hubungan aspek-aspek kesadaran linguistik dan 
Tabel 7. Hubungan kesadaran linguistik dan persepsi visual dengan aspek-aspek kemampuan membaca

\begin{tabular}{|l|c|c|c|c|c|}
\hline \multirow{2}{*}{ Variabel } & \multicolumn{5}{|c|}{ Kemampuan Membaca } \\
\cline { 2 - 6 } & Huruf & $\begin{array}{c}\text { Suku } \\
\text { kata }\end{array}$ & Kata & kalimat & Keseluruhan \\
\hline Fonem & 0,90 & 0.92 & 0.91 & 0.87 & 0,90 \\
Morfem & 0,89 & 0,92 & 0,91 & 0,87 & 0,89 \\
Simantik & 0,79 & 0,55 & 0,94 & 0,92 & 0,80 \\
Sintaksis & 0,80 & 0,98 & 0,97 & 0,95 & 0,92 \\
Diskriminasi bentuk & 0,90 & 0,81 & 0,82 & 0,74 & 0,81 \\
Spasial & 0,95 & 0,80 & 0,80 & 0,72 & 0,81 \\
Figur \& Ground & 0,91 & 0,68 & 0,68 & 0,58 & 0,71 \\
Memori & 0,98 & 0,92 & 0,93 & 0,86 & 0,92 \\
\hline
\end{tabular}

*Pearson Correlation Test (pd"0,05)

persepsi visual yang paling esensial terhadap membaca kata, yang paling kuat, yaitu ada pada aspek sintaksis dari kesadaran linguistik dengan koefisien korelasi sebesar 0,97 sedangkan yang paling kecil adalah figur ground dari presepsi visual dengan koefisien korelasi 0,68, meskipun masih termasuk dalam kategori kuat. Begitu pula dengan hubungan aspek-aspek kesadaran linguistik dan persepsi visual yang paling esensial terhadap membaca kalimat, yang paling kuat yaitu pada aspek sintaksis dari kesadaran linguistik dengan koefisien korelasi sebesar 0,95 sedangkan yang paling kecil terjadi pada aspek figur-ground dari persepsi visual dengan koefisien korelasi 0,58 meskipun masih termasuk pada kategori kuat.

Hubungan tersebut dikelompokkan, kemudian diperbandingkan rerata nilainya pada aspek kesadaran linguistik dan persepsi visual berdasarkan kualifikasi membaca dapat dijelaskan pada Tabel 8.
Tabel 8, menunjukkan bahwa rerata pada aspek kesadaran linguistik seperti untuk fonem dalam kualifikasi membaca baik, diperoleh angka rata-rata 0,85 , dengan simpangan baku 0,24 dan berdasarkan hasil uji statistik Analysis of varians menunjuk pada derajat kepercayaan 95\% ketika angka itu lebih tinggi dibandingkan dengan kelompok kualifikasi sedang dan buruk. Ini berarti adanya perbedaan kebermaknaan rerata dalam aspek kesadaran linguistik dalam hal fonem berdasarkan kualifikasi membaca dengan perolehan nilainya adalah $p=0,005$ (nilai pd"0,05).

Sementara rerata aspek kesadaran linguistik dalam morfem, pada kelompok kualifikasi membaca baik, diperoleh nilai yang sama yaitu 0,85 dengan simpangan baku 0,23. Hasil uji statistik Analysis of varians menunjuk pada derajat kepercayaan $95 \%$ ketika angka itu lebih tinggi dibandingkan dengan kelompok kualifikasi sedang

Tabel 8. Perbandingan rerata nilai aspek kesadaran linguistik dan persepsi visual yang paling esensial berdasarkan kualifikasi membaca

\begin{tabular}{|l|c|c|c|c|c|c|c|c|}
\hline \multirow{3}{*}{ Variabel } & \multicolumn{7}{|c|}{ Kualifikasi Membaca } & \multicolumn{2}{c|}{ F $_{\text {Hitung }}$} & \multirow{2}{*}{ Nilai $\mathrm{p}^{*}$ ) } \\
\cline { 2 - 7 } & \multicolumn{2}{|c|}{ Baik } & \multicolumn{2}{c|}{ Sedang } & \multicolumn{2}{c|}{ Buruk } & \\
\cline { 2 - 7 } & Rerata & SB & Rerata & SB & Rerata & SB & & \\
\hline Fonem & 0,85 & 0,24 & 0,61 & 0,18 & 0,55 & 0,16 & 6,306 & 0,005 \\
\hline Morfem & 0,85 & 0,23 & 0,69 & 0,17 & 0,60 & 0,14 & 5,315 & 0,011 \\
\hline Simantik & 0,87 & 0,34 & 1,00 & 0,00 & 0,88 & 0,14 & 1,016 & 0,375 \\
\hline Sintaksis & 0,75 & 0,31 & 0,32 & 0,06 & 0,29 & 0,25 & 9,388 & 0,001 \\
\hline Diskriminasi & 0,90 & 0,11 & 0,72 & 0,14 & 0,77 & 0,19 & 2,090 & 0,142 \\
\hline Spasial & 0,96 & 0,10 & 0,71 & 0,11 & 0,71 & 0,29 & 2,824 & 0,076 \\
\hline Figur Ground & 1,00 & 0,00 & 0,84 & 0,21 & 0,66 & 0,37 & 3,189 & 0,056 \\
\hline Memori & 0,86 & 0,21 & 0,50 & 0,25 & 0,42 & 0,33 & 5,472 & 0,010 \\
\hline
\end{tabular}

*Analysis of Varians $\left(\mathrm{pd}^{\prime \prime} 0,05\right)$ 
dan buruk. Ini berarti adanya perbedaan kebermaknaan rerata dalam aspek kesadaran linguistik dalam hal morfem berdasarkan kualifikasi membaca dengan perolehan nilai $p=0,011$ (nilai pd"0,05).

Begitu pula dengan rerata aspek kesadaran linguistik dalam simantik pada kelompok kualifikasi membaca baik, lebih tinggi dibandingkan dengan kelompok kualifikasi sedang dan buruk, yaitu 0,87 dengan simpangan baku 0,34, namun hasil uji statistik menunjukkan bahwa tidak terdapat perbedaan kebermaknaan rerata pada aspek kesadaran linguistik dalam pada aspek simantik di mana berdasarkan kualifikasi membaca diperoleh nilai $p=0,375$ (nilaip $>0,05$ ).

Data lain menunjukkan rerata pada aspek kesadaran linguistik dalam sintaksis untuk kelompok kualifikasi membaca baik, lebih tinggi dibandingkan dengan kualifikasi sedang dan buruk sebesar 0.75 dengan simpangan baku 0.31. Hasil uji statistik menunjukkan bahwa terdapat perbedaan kebermaknaan rerata pada aspek kesadaran linguistik dalam hal sintaksis berdasarkan kelompok kualifikasi membaca dengan nilai $p$ $=0.001$ (nilai pd"0.05)

Hal yang sama juga diperlihatkan rerata pada aspek persepsi visual yaitu pada aspek diskriminasi pada kelompok kualifikasi membaca baik, lebih tinggi dibandingkan dengan kualifikasi sedang dan buruk yaitu 0.90 dengan simpangan baku 0.11. Namun, hasil uji statistik menunjukkan bahwa tidak terdapat perbedaan kebermaknaan rerata pada aspek presepsi visual seperti pada diskriminasi bentuk berdasarkan kualifikasi membaca di mana nilai $p=0.142$ (nilaip $>0.05$ ). Hal yang sama terjadi pada perolehan rerata dari aspek presepsi visual dalam hal spasial pada kelompok kualifikasi membaca baik, lebih tinggi dibandingkan dengan kualifikasi sedang dan buruk yaitu 0.96 dengan simpangan baku 0.10. Namun, hasil uji statistik menunjukkan bahwa tidak terdapat perbedaan kebermaknaan rerata dalam aspek spasial berdasarkan kualifikasi membaca dengan nilai $p=0.076$ (nilai $p>0.05$ ).

Rerata aspek presepsi visual yang berkaitan dengan figur-ground pada kelompok kualifikasi membaca baik, juga lebih tinggi dibandingkan dengan kualifikasi sedang dan buruk yaitu 1.00. Namun, hasil uji statistik menunjukkan bahwa tidak terdapat perbedaan kebermaknaan rerata pada aspek presepsi visual pada figur-ground berdasarkan kualifikasi membaca dengan nilai $p$ $=0.056$ (nilaip $>0.05$ ). Berbeda dengan rerata aspek presepsi visual seperti pada memori pada kualifikasi membaca baik, lebih tinggi dibandingkan dengan kualifikasi sedang dan buruk yaitu 0.86 dengan simpangan baku 0.21 dan hasil uji statistik menunjukkan bahwa terdapat perbedaan kebermaknaan rerata pada aspek presepsi visual dalam hal memori berdasarkan kualifikasi membaca dengan nilai $p=0.010$ (nilaip $>0.05$ )

Pengaruh kesadaran linguistik dan kesadaran persepsi visual yang paling esensial terhadap kemampuan membaca, ternyata masalah kesadaran linguistik khususnya pada aspek kesadaran bunyi fonem dan sintaksis merupakan faktor yang berpengaruh kuat terhadap kemampuan membaca, sementara aspek yang berkaitan dengan morfem dan simantik sekalipun memiliki hubungan yang kuat, ternyata tidak memiliki kebermaknaan secara positif terhadap kemampuan membaca. Tidak adanya timbal balik pengaruh antara bunyi morfem dan simantik dalam kaitannya dengan masalah membaca, masingmasing aspek dimaknai secara terpisah-pisah oleh anak, sehingga tidak memiliki kaitan dan kebermaknaan. Jika diamati struktur bahasa, hubungan antara pembentukkan, morfem, dan simantik tidak menunjukkan garis lurus kebermaknaannya, Sebagai contoh; gabungan dua bunyi morfem antara "ber" sebagai morfem terikat dan "main" sebagai morfem bebas pada kata -bermain, yang menunjuk pada kata keterangan akan dimaknai sama dengan kata "main" sebagai kata kerja, sehingga makna bunyi "ber" yang menunjuk pada keterangan tidak dapat dimaknai dengan baik. Akan tetapi, makna dari kata bermain akan berbeda dimaknai jika ada dalam struktur kalimat misalnya, "Si Amir sedang bermain bola". Makna siapa yang bermain, apa yang dilakukan si Amir menjadi lebih mudah untuk dapat dipahami anak. Hal ini juga berkaitan dengan perkembangan bahasa anak tunagrahita yang kurang sempurna. Kalimat-kalimat mereka sering sekali sederhana seperti, "Si Ahmad sedang berlarilari di halaman" akan disederhanakan menjadi "Ahmad lari di halaman", "ibu sedang membaca koran" menjadi "ibu baca koran" (Suhaeri dan Purwanto, 1992) 
Analogi ini juga dapat dilihat dari proses komunikasi dengan anak. Anak tunagrahita (ringan) ketika mereka diajak berbicara dapat berkomunikasi dengan baik. Mereka akan memberikan jawaban-jawaban ketika ditanya, bahkan mereka dapat balik bertanya sesuai alur pembicaraan. Akan tetapi jika mereka diminta untuk menjelaskan satu kata dari apa yang dibicarakan, belum tentu dapat menjelaskan makna dari setiap kata tersebut. Sebagai ilustrasi; ketika mereka ditanya 'sekarang kamu kelas berapa ?, diantar siapa, naik apa ke sekolah? pada batas tertentu mereka dapat memberikan alasan ketika ditanya mengapa harus diantar ibu ?. Akan tetapi ketika mereka ditanya apa arti dari kata; naik, ibu, sekolah, atau sekarang mereka sukar sekali menjelaskan kata-kata itu. Dengan demikian, sesungguhnya pemahaman makna kata itu dimiliki atau dipahami anak, namun tampaknya harus dalam konteks yang menyeluruh atau utuh seperti dalam bentuk kalimat atau frase. Hal ini sejalan dengan teori Gestalt bahwa suatu yang diamati (objek) akan segera muncul dalam pengamatan anak (seseorang) secara keseluruhan, bagian-bagian dari objek itu justru akan muncul kemudian. Jika teori ini kemudian dikaitkan dengan persoalan bahasa nampaknya menjadi sangat logis, sebab masalah tutur kata dalam sebuah kalimat atau frase (sintaksis) merupakan keseluruhan makna (Gestalt) yang utuh dan segera akan dipahami anak.

Apabila yang menjadi faktor esensial dari kesadaran linguistik sebagai prasyarat dalam membaca terletak pada penguasaan kesadaran akan bunyi fonem dan sintaksis maka dalam proses belajar membaca pada anak tunagrahita harus diawali dengan melatih terlebih dahulu kedua persoalan yang berkaitan dengan kesadaran akan bunyi fonem dan pemahaman akan makna kalimat atau prase (sintaksis), baru kemudia masuk kepada persoalan membaca yang sesungguhnya.

Aspek lain yang turut berpengaruh, terhadap kemampuan membaca juga terjadi pada kesadaran persepsi visual, khususnya pada aspek kesadaran diskriminasi dan ingatan visual (visual memory). Jika kedua aspek tersebut menjadi faktor yang cukup esensial terhadap membaca, kemudian dikaitkan dengan kondisi anak tunagrahita maka kecenderungan itu terjadi sebagai akibat dari kondisi anak yang pada umumnya mengalami hambatan dalam masalah memory. Pendeknya rentang kemampuan dalam hal mengingat adalah ciri khas yang terjadi pada mereka. Sementara hal-hal yang berkaitan dengan masalah diskriminasi pada anak tunagrahita juga sering menjadi masalah. Banyak diantara mereka yang sering terbalik di dalam mempersepsi sesuatu termasuk dalam mempersepsi simbol bahasa (huruf). Jika sesuatu yang dilihat berbeda dengan apa yang dipersepsi maka akan terjadi kesalahan makna. Apabila masalah diskriminasi dan memori kemudian dikaitkan dengan persoalan membaca maka pada dasarnya apa yang dibaca merupakan deretan huruf. Setiap huruf memiliki bentuk dan bunyi yang berbeda. Kesalahan dalam mempersepsi bentuk huruf dapat menimbulkan kesalahan yang bukan hanya dalam bunyi dari huruf, melainkan juga makna dari yang dibacanya. Sementara proses untuk dapat memahami perbedaan huruf yang satu dengan bentuk huruf lainnya erat kaitannya dengan proses kognitif yang dalam hal ini menyangkut diskriminasi dan memori

\section{Simpulan dan Saran}

\section{Simpulan}

Berdasarkan analisis statistik sebagaimana yang telah digambarkan maka dapat ditarik simpulan bahwa pada dasarnya dalam proses belajar membaca permulaan sekurang- kurangnya ada dua tahapan. Pertama, berkaiatan dengan penguasaan prasyarat yang dalam hal ini adalah prasyarat yang berkaitan dengan penguasaan kesadaran bunyi fonem, sintaksis, kesadaran dalam diskriminasi bentuk dan memori, dimana tahapan ini menjadi satu kesatuan dalam keseluruhan proses membaca. Kedua, belajar membaca itu sendiri, yang dalam prosesnya harus melibatkan kedua sensor yaitu auditori dan visual

Kedua aspek dari prasyarat membaca yang berkaitan dengan kesadaran linguistik dan klesadaran persepsi visual memiliki hubungan kuat terhadap kemampuan membaca permulaan anak tunagrahita (ringan). Namun, ika kita dilihat berdasarkan Koefisien Beta secara parsial tampak bahwa aspek kesadaran linguistik memiliki hubungan yang jauh lebih kuat dibandingkan 
dengan hubungan yang ditunjukkan pada aspek kesadaran persepsi visual. Nilai koefisien path pada kesadaran linguistik menunjuk pada besaran angka 0.72 sementara pada kesadaran peresepsi visual besaran angka nilai koefisien pathnya menunjuk pada angka 0.25. Ini berarti aspek kesadaran linguistik memiliki posisi yang lebih berarti sebagai prasyarat dalam belajar membaca pada anak tunagrahita ringan dibandingkan dengan aspek kesadaran persepsi visual. Akan tetapi apabila ditelaah lebih lanjut, ternyata tidak semua variabel yang berkaitan dengan aspek kesadaran linguistik maupun kesadaran persepsi visual memiliki kebermaknaan hubungan yang sama terhadap kemampuan membaca anak.

Faktor yang paling esensial sebagai prasyarat membaca yang berkaitan dengan aspek kesadaran linguistik ternyata hubungannya lebih berkaitan dengan kesadaran bunyi fonem dan sintaksis. Sementara faktor esensial yang menjadi prasyarat membaca yang berkaitan dengan aspek kesadaran persepsi visual hubungannya lebih berkaitan dengan diskriminasi bentuk (visual discrimination) dan ingatan visual (visual memory).

\section{Saran}

Atas dasar simpulan maka disarankan agar dalam pembelajaran membaca guru mempertimbangkan perlunya prasyarat yang brkaitan dengan masalah kematangan. Hal ini akan berakibat pada keberhasilan mengajar membaca pada anak tunagrahita. Manakala kematangan belum dipenuhi, akan menimbulkan banyak kegagalan dalam proses belajar membaca berikutnya. Sebaliknya, jika hal ini dipaksakan maka akan banyak muncul akumulasi kegagalan yang menyebar pada semua aspek kesiapan belajar membaca.

Disamping itu, guru diharapkan mampu mendeteksi berkaitan dengan pemenuhan kesiapan tersebut sedini mungkin, sehingga tidak berakibat fatal terhadap hasil belajar mereka. Pemahaman terhadap prasyarat ini menjadi bagian penting yang harus diketahui seorang guru dalam pembelajaran membaca

Dalam pembelajaran membaca Guru diharapkan menguasai tahapan yang berkaitan dengan pengusaan kesadaran bunyi fonem, sintaksis, kesadaran dalam diskriminasi bentuk dan visual memori. Belajar membaca itu sendiri dalam prosesnya harus melibatkan kedua sensor auditori dan visual

Guru diharapkan mampu melaksanakan prinsif prinsif pembelajaran membaca, yaitu 1) keterlibatan fungsi auditori-visual sebagai suatu proses terjadinya keterlibatan antara kesadaran kinguistik (fonem dan sintaksis) dan kesadaran persepsi visual (diskriminasi bentuk dan visual memori), melalui proses diskriminasi bentuk dan bunyi. 2) repetisi sebagai proses belajar yang dilakukan secara berulang-ulang baik secara auditori maupun visual serta hubungan di antara keduanya.

Hal lain yang perlu dipahami dan dikuasai guru berkaitan dengan reposisi bunyi dan simbol dari bunyi tersebut. Sekali bentuk dan bunyi dikacaukan oleh adanya perubahan posisi maka kegagalan membaca akan terus terakumulasi. Oleh karena itu peran sensor kinestetik menjadi bagian penting dalam proses reposisi bunyi.

\section{Pustaka Acuan}

Bryant P \& Bradly.L. 1998. Catagorizing sounds and learning to read-acausal connection, Nature. 193199.

Bradley, L., Bryant. P. 1991. "Visual Memory and Phonological Skill in Reading and Spelling Backwardness". Psychol Res. 43,

Cohen. 1996. Cognition, .Singapure: McGraw-Hill Book Comapany

Colin Rose \& Malcolm J. Nicholl. 2002. Beginning Reading Instruction, Paper presented at the Educational Policy Group Conference, Washington.

Cunningham, A.F. 1990. Explicit versus implicit instruction in phonemic awareness, Journal of Experiment Child Psychology, Nature; 189 
Gardner. 1998. Multiple Intellegences, Myths and massages. In A. Woolfolk (Ed), reading in Educational Psychology. Boston Allan \& Bacon.

Harris ,A.J. \& Sipay,ER 1990. How to Increase Reading Ability: A Guide to Developmental and Remidial Method, New York: Longman

Hatcher, Hulme \& Ellis. 1994. Perspectives on literacy and axtensions to educational practice. In.D.C.Berliner \& R.C. Calfee. New York: Macmillan

Herawati Dewi. 2007. Kesadaran Linguistik dengan Keterampilan Membaca Permulaan pada aak Tunagrahita, Srkipsi, plb-fip.Upi Bandung

Lyster, S.A.H. 2002. In Press. The effectes of Morphological Versus Phonological Awarneness training In Kindergarten on Reading Development. Reading and Writing: An Interdisiplinary Jurnal.

Molyono Abdurrahman. 1999. Pendidikan Bagi Anak Berkesulitan Belajar, Rineka Cipta, Jakarta.

Rahim. Farida. 2007. Pengaaran Membaca di Sekolah Dasar, Bumi Aksara, Jakarta.

Santrock. Jhon.W. 2007. Educational Psychology, McMgraw-Hill Company, Inc. All rights reserved

Santrock John W. 2007. Educational Psychology, McGrow-Hill. Company, Inc

Sk. Sitepu Nirwana. 1995. Aplikasi Statistik, Gramedia Pustaka-Jakarta

Suhaeri HN \& Edi Purwanto. 1992. Bimbingan Konseling Anak Luar Biasa

Somatri Ating dan Sambas. 2006. Aplikasi Statistika dalam Penelitian, Pustaka Setia, Bandung.

Slamet Ahmad Harjasujana, Damayanti Vismaia. S. 2003. Membaca dalam Teori dan Praktek, Mut. 